Surely the most important information - the drug's generic name and concentration - should be the prominent fealure on the label. Only $3 \%$ of the label is used to describe the drug concentration whereas over $9 \%$ of the area is used for the drug's proprietary name. It is interesting to review the labels on the drugs contained in the anaesthelic cart and to note the relative area used for the proprietary name and manufacturer's logo. Labels should not serve as advertisements in the operating room. Rather, standards need to be improved to ensure that patient safety is the priority.

Beverley A. Orser MD FRCPC PhD

Department of Anaesthesia

University of Toronto

2075 Bayview Avenue

North York, Ontario M4N 3M5

Phone: (416) 480-4864. Fax: (416) 480-6039.

REFERENCE

I Ahdal $O A$, Bevan DR. Clindamycin-induced neuromuscular blockade. Can J Anacsth 1995; 42: 614-7.

\section{Le dextrométorphan en anesthésie}

\section{A la rédaction:}

Nous désirons communiquer à vos lecteurs les résultats d'un travail préliminaire sur le dextrométhorphan (DM). L.' accélération de la décharge neuronale de la corne postérieure après un stimulus douloureux soutenu serait inhibéc par les antagonistes des récepteurs NMDA comme le DM. Le DM un inhibiteur des récepteurs NMDA pourrait prévenir ou pour le moins diminuer la «mémoirc douloureuse» au niveau du SNC et permettre de mieux contrôler la douleur postopératoirc.' Pour valider cettc hypothèse, nous avons entrepris une étude prospective et en double aveuglc chez des patientes programmées pour hystérectomie abdominale réglée afin de vérifier si le DM pouvait stabiliser l'anesthésie et diminuer les besoins postopératoires en morphine. ${ }^{2}$

Pendant la chirurgie, nous n'avons pas noté de différence entre les groupes au regard de la pression artérielle moyenne. En postopératoire, ni la consommation de morphine ni l'évaluation subjective de la douleur n'a différé entre les deux groupes. La kétamine, un inhibitcur non spécifique des récepteurs NMDA réduit, à faible dosc, la consommation de morphinè à la période postopératoire. ${ }^{2}$ Le DM, un antitussif est, comme la kétamine, un inhibiteur non spécifique des réceptcurs NMDA sans les effets secondaires de la codéine comme la somnolence et les troubles gastro-intestinaux. On ne connaît pas la dose de DM nécessaire pour bloquer les récepteurs NMDA chez l'humain. Nos résultats indiquent que, sur un nombre limité de patientes, le DM $60 \mathrm{mg}$ per os administré une heure avant la chirurgie, ne semble pas influencer l'accélération de la décharge neuronale alors que chez le rat, 5 $\mathrm{mg} \cdot \mathrm{kg}^{-1} i v$ ont été efficaces. ${ }^{3}$ Pour obtenir des résultats identiques, nous aurions peut-être dô augmenter la posologie ou utiliser la voie $i v$ comme pour la kétamine.

Nous croyons que le DM pourrait être intéressant pour l'élude du phénomène d'inhibition des récepteurs NMDA. ${ }^{5}$ Cependant, la dose de $60 \mathrm{mg}$ per os administrée à des adultes ne prévient ni la douleur ni ne diminue la consommation postopératoire de morphine.
Pierre Dolbec MD FRCPC

Denys Dolbec Ing.

Gilles Gendron MD FRCPC

Richard Fortin MD FRCPC

Hôtel-Dieu de. Lévis

143 rue Wolfe

Lévis, Québec G6V 3Z1

\section{REFERENCES}

I Dickerson AH. NMDA receptor antagonists as analgesics. In: Fields HL, Liebesking JC (Ed.). Progress in Pain Research and Management Vol. 1, IASP Press, Seattle, 1994; 173-87.

2 Roytblat L, Korotkoruchko A, Katz J, Glazer M, Greemberg $L$, Fisher A. Postoperative pain: the effect of low dose ketamine in addition to general anesthesia. Anesth Analg 1993; 77: 1161-5.

3 Dickerson AH, Sullivan AF, Stanfa LC, McQuay HJ. Dextromethorphan and levorphanol on dorsal horn nociceptive neurones in the rat. Neuropharmacol 1991; 30:1303-8.

4 Elliout $K J$, Brodwky M, Hynansky $A D$, Foley $K M$, Inturrisi $C E$. Dextromethorphan suppresses both formalin-induced nociceptive behavior and the formalin-induced increase in spinal cord c-FOS mRNA. Pain 1995; 61: 401-9.

\section{Anaesthetic management in patients with asthma}

To the Editor:

The "Anaesthetic management of an asthmatic child for appendicectomy" with epidural anaesthesia was recently described by Kuwahara and Goresky. ${ }^{\text {T }}$ This case report highlights the analysis of the risk/benefit ratio of regional and general anaesthesia in asthma. However, two points may be further discussed. First, although we agree that regional anaesthesia should be preferred when possible in patients with asthma, ${ }^{2}$ it should be remembered that both spinal and epidural anaesthesia may also provoke bronchospasm ${ }^{3.4}$ by the combination of neural blockade involving the adrenal gland $\left(\mathrm{T}_{10}-\mathrm{L}_{1}\right)^{3.5}$ and the sympathetic pathways in the lungs $\left(\mathrm{T}_{1-4}\right)^{4,5}$ Thoracic sympathetic tone is supposed to prevent increase in airway resistance mostly by modulating acetylcholine output and/or by restricting bronchial blood flow. ${ }^{5}$ The inhibition of this sympathetic pathways may explain why bronchospasm has been rcported only when the sensory blockade reaches or exceeds the $\mathrm{T}_{4-5}$ level. ${ }^{3.4}$ Unfortunately, blockade up to the $\mathrm{T}_{4-5}$ level is required for intraperitoneal surgery and in Kuwahara's report, the $\mathrm{T}_{7}$ upper level initially obtained was insufficient, as expected. The addition of $13 \mathrm{ml}$ lidocaine $1.5 \%$ probably spread the blockade at least to $\mathrm{T}_{4-5}$. Thus, abdominal surgery, even best performed in asthmatics under general regional anaesthesia, carries a potential risk of bronchoconstriclion. Second, it is stated in the discussion that "pancuronium is the musclc relaxant of choice in patients with asthma." We agree that "neuromuscular blocking agents capable of inducing histamine release are best avoided in asthmatics." However, since vecuronium does not induce histamine release, the use of this drug should also be weighed against that of pancuronium. An 